\title{
Notes on the poetics of Caryl Churchill's Escaped Alone
}

\section{October 2018 - Fiona Templeton}

(I came to writing for performance from writing and reading poetry, and from creating performances without writing. As reading, most plays seemed empty; in performance, redundant, as the action would be doing it anyway, a relentless doubling. That emptiness can of course be the time of the body and of relation. My co-created Going ${ }^{i}$ (Theatre of Mistakes, 1977 and 2017) has a dozen lines played in permutation; emptiness, silence and time are gradually filled in. Poetry pushes out a time and space within itself, its density multiplying resonances. The convention of verisimilitude in some plays can't let verbal density in, though life's not like that.)

Caryl Churchill's recent work re-stages silence and density, emptiness and doubling.

The script of Escaped Alone $e^{i i}$ doesn't differentiate in stage directions between what is said to others and the verbally very different passages that are spoken to.. to whom? heard by whom? In the Royal Court production, the garden where the five "at least seventy" year old women chat was visually obliterated during the monologue speeches of Mrs. J. But what is said in the garden, to others, is full of speaking the unspoken. Sally in her cat phobia can't bear to hear even the word, but the others talk about not talking about it. The story of the TV series would be a spoiler, but they find it hard to not say it. Vi tells how she killed someone, not even remembering whether or not it was murder, while Sally, the witness, says that what Vi thinks is so must be the truth, no matter what she herself saw.

The banalities within which these tellings are embedded are clipped, half-expressed, unfinished in common understanding, unfinished because not listened to, always about to dry up. Words or echoing fragments cover silences but are riddled with holes, an emptiness of speaking but not saying. Or rather saying matters of life and death is not different to parroting trivia. Unexpected knowledges surface, like a googolplex, but not knowing or not remembering wield more power, that of silencing while enacting communication. But there's also a void underneath.

Mrs. J's apocalyptic tirades are not personal. They speak after the fact, in the plural, about others, about horror. They are single paragraphs. Details are gruesome and politicized, fantastical yet full of real fear. They are solid on the page and separated from the dialogues in the script only by space and by coming at the end of sections. In poetry, space on the page is used in many ways but also reminds us that the time of making includes what is not written. The Royal Court staging shift not only hid the garden in darkness but was another kind of reality, an abstract one, and Mrs. J left her garden chair to rail in a cracking voice in this other world.

The images that cascade too quickly in Mrs. J's speeches move all the faster for their unlikely detail, a poetic reinforcement of what drives them. These tellings, though in the past, sound less like remembering than like creating. Word-choices repeatedly jolt us awake: "The chemicals leaked 
through cracks in the money." From a concrete image we are forced to see another picture. This is not functioning as a metaphor. It's the shock of a truth. The blame lies on power and on believing in it.

The worlds told of are excess and scarcity, desperate loneliness and masses, what is escaped from and what can't be survived sane. They are milling with detail but we feel that under this surface is more and more detail, more horror.

The monologues are not confessional. Some other characters speak at length but subjectively. Th monologues are large, plural, naming forces at work to undermine the populace, against the thirsty, against children, against...

The summarizing tirade, however, is dropped seamlessly into the stumbling-along dialogue: "terrible rage terrible rage terribe rage terrible rage..." over and over 26 times. It is not fear but rage that erupts. Vi's killing is relived as fear of the kitchen, but whatever rage prompted it isn't raised. Mrs. J's difference is that she tells it. No-one listens.

The play's epigraph, from Moby Dick, "I only am escaped alone to tell thee,"iii suggests a survivor's memory. But what good does telling do? Is she telling us, the audience, as seemed to be staged at the Royal Court and implied by the visual separation of the paragraphs? Is she telling her companions? Is she the only one actually able to say something? The others have lived their own horrors, but she escapes from the fenced garden of their not-telling. Is the terrible rage her own or is she the voice of their terrible rage? "And then I said thanks for the tea and I went home." Is the rage at home? Or in the garden? Is her telling, her difference as the teller, why she remains "that woman", the only one with no first name? It is all of these, and that density of ambiguity is poetic.

\footnotetext{
'The Theatre of Mistakes, Going, premiered Edinburgh College of Art 2017; recreated at Raven Row, London 2017, direted by Fiona Templeton.

ii Caryl Churchill, Escaped Alone, premiered Royal Court, London 2016; published NHB Modern Plays 2016.

iii "Book of Job. Moby Dick," as cited in the published play, above.
} 